\title{
Micropropagation of Costus speciosus (Koen.) Sm. Using Nodal Segment Culture
}

\author{
Kshetrimayum PUNYARANI, G. Jitendra SHARMA \\ Manipur University, Department of Life Sciences, Imphal-795003, India; punyaraniksh@gmail.com; gjs1951@yahoo.com
}

\begin{abstract}
Nodal segments of Costus speciosus (Koen.) Sm. containing single axillary buds were cultured on Murashige and Skoog medium (MS medium) supplemented with plant growth regulators for inducing plantlets. For breaking of axillary bud dormancy, nodal segments were cultured on 40-70 $\mathrm{gl}^{-1}$ sucrose or 1-13 $\mu \mathrm{M}$ adenine sulphate (AdS) supplemented MS basal medium containing $5 \mu \mathrm{M}$ 6-benzylaminopurine (BAP) and $1 \mu \mathrm{M} \alpha$-naphthalene acetic acid (NAA). The nodal segments cultured on 1-13 $\mu \mathrm{M}$ AdS, $5 \mu \mathrm{M}$ BAP, $1 \mu \mathrm{M}$ NAA and $50 \mathrm{gl}^{-1}$ sucrose showed simultaneous production of shoots and roots while those cultured on $5 \mu \mathrm{M}$ BAP, $1 \mu \mathrm{M}$ NAA and $40-70 \mathrm{gl}^{-1}$ sucrose

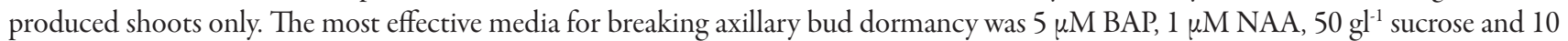
$\mu \mathrm{M}$ AdS supplemented medium. The propagules from $40-70 \mathrm{gl}^{-1}$ sucrose produced roots in shoot multiplication medium, i.e., $10 \mu \mathrm{M}$ AdS, $1 \mu \mathrm{M}$ NAA, $50 \mathrm{gl}^{-1}$ sucrose and 3-11 $\mu \mathrm{M}$ BAP supplemented medium. The best response for shoot multiplication was on $10 \mu \mathrm{M}$ AdS, $1 \mu \mathrm{M}$ NAA, $50 \mathrm{gl}^{-1}$ sucrose and $7 \mu \mathrm{M}$ BAP. The well-rooted shoots were hardened and transferred to the soil where they showed $95 \%$ survival rate. Results show that axillary bud can be used for micropropagation of Costus speciosus.
\end{abstract}

Keywords: costus speciosus, micropropagation, adenine sulphate, axillary bud

\section{Introduction}

About 150 species of Costus speciosus (Koen.) Sm. (family: Costaceae) have been reported from the tropical regions of the world (Deb, 1983). The decoction of roots of Costus speciosus are prescribed in urinary complaints and are stimulant, tonic, and antihelmintic. Rhizome extract, paste and juice are applied to cure white leprosy, juice poured in earache, eaten with sugar to expel intestinal worms, cooked and eaten as laxative (Prakash and Mehrotra, 1996). The root extract acts as an astringent, aphrodisiac, depurative, purgative and is useful in catarrhal fever, cough, skin diseases and snake bites (Khanna et al., 1977; Rathore and Khanna, 1978; Rastogi and Mehrotra, 1991). The rhizomes can be used as an alternative source of diosgenin (Chopra et al., 1956; Dasgupta and Pandey, 1970). The main advantage of Costus speciosus over the two species of Dioscorea is that $C$. speciosus grows abundantly in the plains, whereas both $D$. prazeri and $D$. deltoidea grow only at high altitudes of the Himalayas (Dasgupta and Pandey, 1970). Eremanthin and costunolide isolated from Costus speciosus possessed hypoglycemic and hypolipidemic activities (Eliza et al., 2009 a and b). However, the existence of this species has been threatened due to deforestation, jhum cultivation, habitat disturbance for conversion of wetland ecosystem into agricultural land and uncontrolled plucking/uprooting of these plants. Shoot multiplication in Costus speciosus have been achieved using shoot tips (Chaturvedi et al., 1984) and rhizome thin sec- tions (Malabadi et al., 2005). Micropropagation through rhizomatous eyes/ buds/ shoot tips or rhizome thin sections has disadvantages: the uprooted rhizomes usually fail to survive after rhizomatous eyes/ shoot tips are decapitated, and establishment of in vitro culture is usually difficult due to higher contamination. The present investigation, therefore, is an attempt to develop mass propagation protocol using nodal segments of stem. Micropropagation using nodal segments overcomes many disadvantages of rhizomatous eye/bud/shoots tip culture. In nodal segment culture, contamination is less, mature stem which have produced seeds are used and one mature stem usually contain 15-20 axillary buds in comparison to 4-5 rhizomatous eyes in one rhizome.

\section{Materials and methods}

Stems of C. speciosus (Koen.) Sm. were collected from the Experimental Field of Manipur University. The leaf sheaths covering the stem were removed and then the stems were washed under running tap water for 15 mins. The stems were then cut into segments, each segment containing one axillary bud. The nodal segments were surface decontaminated in $0.1 \% \mathrm{HgCl}_{2}$ (10 mins.) before rinsing with sterilized distilled water. Nodal segments were cultured in $250 \mathrm{ml}$ conical flasks (Borosil), each containing $15 \mathrm{ml}$ of MS medium supplemented with various plant growth regulators (PGRs) and sucrose concentration. The $\mathrm{pH}$ of the media was adjusted to 5.8 before being auto- 
claved at $121^{\circ} \mathrm{C}$ for $20 \mathrm{~min}$ and $15 \mathrm{lbs} \mathrm{sq}$ inch ${ }^{-1}$ pressure. All cultures were incubated at $25 \pm 2^{\circ} \mathrm{C}$ under $16 \mathrm{~h}$ (day/ night) photoperiod with light supplied by white fluorescent tubes (3000 lux). Subculturing was carried out after every 4 weeks by trimming-off leaves and roots. For breaking the dormancy of the bud, the nodal segments were cultured on MS medium supplemented with $5 \mu \mathrm{M}$ BAP, $1 \mu \mathrm{M}$ NAA, $50 \mathrm{gl}^{-1}$ sucrose and 1-13 $\mu \mathrm{M}$ AdS or $5 \mu \mathrm{M}$ BAP, $1 \mu \mathrm{M}$ NAA and 30-70 $\mathrm{gl}^{-1}$ sucrose. The cultures were maintained for induction of bud-break. The freshly initiated plantlets/ shoots were subcultured on MS medium (Murashige and Skoog, 1962) supplemented with $10 \mu \mathrm{M}$ AdS, $1 \mu \mathrm{M}$ NAA, $50 \mathrm{gl}^{-1}$ sucrose and 3-11 $\mu \mathrm{M}$ BAP for shoot multiplication.

Each treatment had 10 replicates and data were recorded after 4 weeks. For bud break induction, it was repeated three times while for shoot multiplication experiment, it was repeated two times. All the data were scored after four weeks of culture. Data were analyzed for significance using ANOVA and the differences contrasted using Tukey's comparison tests at $5 \%$ probability test. All statistical analysis was performed using the SPSS statistical software package.

\section{Results and discussion}

In natural habitats, the axillary buds of Costus speciosus are dormant. The present investigation has shown that cutting the stem into segments and culturing them on suitable medium supplemented with suitable PGRs can break the dormancy of the bud. Literature surveys have revealed many possible reasons for this. Auxin makes the shoot apex a sink for cytokinin from the roots and decapitation increases the accumulation of cytokinin in axillary

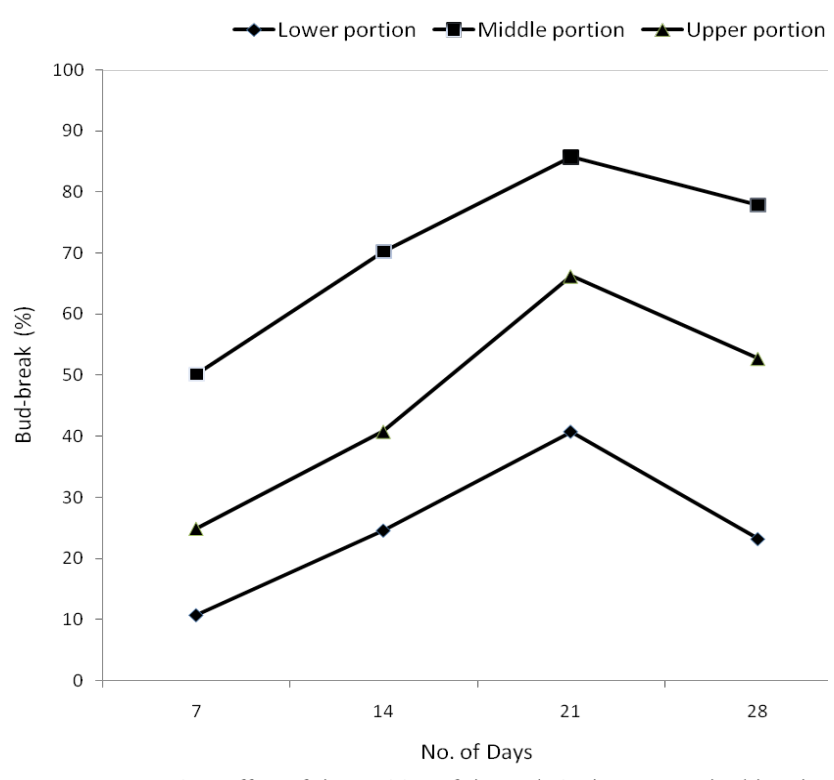

Fig.1: Effect of the position of the node in the stem on bud-break

Fig. 1. Effect of teh position of the node in the stem on budbreak
Tab. 1. Effect of MS medium supplemented with different concentration of sucrose on bud-break in the single node segment culture of Costus speciosus

\begin{tabular}{ccc}
\hline Sucrose $\left(\mathrm{gl}^{-1}\right)$ & Response & Bud-break $(\%)$ \\
\hline 30 & bud enlarged & 51.12 \\
40 & bud differentiated to shoots & 57.36 \\
50 & bud differentiated to shoots & 69.05 \\
60 & bud differentiated to shoots & 61.48 \\
70 & $\begin{array}{c}\text { bud differentiated to shoots } \\
\text { but the leaves turned colorless }\end{array}$ & 53.31 \\
\hline
\end{tabular}

bud (Pilate et al., 1989). Langridge et al. (1989) demonstrated with transgenic plant which contained the genes for bacterial luciferage (LUX A and LUX B) under the control of an auxin responsive promoter that auxin content of the axillary bud increases after shoot apex were decapitated. Hence, it was possible to break bud dormancy in cultured nodal segments due to separation from shoot apex. The position of the nodal buds on the stem did affect bud-break (Fig. 1). Nodal segments taken from the upper and middle portion of the stem showed higher bud-break compared to the nodal segments taken from lower portion of the stem. In Flytrigia repens (quackgrass), the abscissic acid (ABA) level which is usually high in dormant lateral buds declined to $20 \%$ of control level within $24 \mathrm{hrs}$ after the rhizomes were decapitated (Pearce et al., 1995). Hence, the higher bud-break frequency in nodal segments from middle portion of stem may be due to lower level of $\mathrm{ABA}$, in comparison to lower portion of stem; also they are more mature than the upper portion of the stem.

The explants cultured on MS basal medium did not show initiation of bud-break. Success was achieved when the nodal segments were cultured on MS medium supplemented with $1 \mu \mathrm{M}$ NAA, $5 \mu \mathrm{M}$ BAP and 30-70 $\mathrm{gl}^{-1}$ sucrose. After 3 weeks, the highest percentage of shoot induction was observed in the presence of $50 \mathrm{gl}^{-1}$ sucrose (Tab. 1, Fig. 2 a). However, increased percentage of differentiated buds along with roots was observed in MS medium supplemented with $1 \mu \mathrm{M}$ NAA, $5 \mu \mathrm{M}$ BAP, 50 $\mathrm{gl}^{-1}$ sucrose and 1-13 $\mu \mathrm{M}$ AdS (Tab. 2, Fig. 2 b). The highest percentage was found in $1 \mu \mathrm{M}$ NAA, $5 \mu \mathrm{M}$ BAP, 50 $\mathrm{gl}^{\mathrm{l}^{-1}}$ sucrose and $10 \mu \mathrm{M}$ AdS supplemented medium (Tab. 2, Fig. 2 b). The length of the plantlets increased as the concentration of AdS increased. However, $13 \mu \mathrm{M}$ AdS was inhibitory, as decreased in shoot length was observed after achieving maximum length in $1 \mu \mathrm{M}$ NAA, $5 \mu \mathrm{M}$ BAP, 50 $\mathrm{gl}^{-1}$ sucrose and $10 \mu \mathrm{M}$ AdS (Tab. 2, Fig. 2b). The average number of roots decreased as the concentration of AdS increased (Tab. 2). The maximum number of roots was on 1 $\mu \mathrm{M}$ NAA, $5 \mu \mathrm{M} \mathrm{BAP}, 50 \mathrm{gl}^{-1}$ sucrose and $1 \mu \mathrm{M}$ AdS supplemented media, but the axillary bud failed to differentiate to shoots. Therefore, $50 \mathrm{gl}^{-1}$ sucrose and $10 \mu \mathrm{M}$ AdS were considered as optimal for bud-break in C. speciosus. 
60

Tab. 2. Effect of MS medium supplemented with different concentration of adenine sulphate (AdS) and $50 \mathrm{gl}^{-1}$ sucrose on bud-break frequency of single node segment of Costus speciosus

\begin{tabular}{|c|c|c|c|c|}
\hline $\begin{array}{l}\text { Treatment } \\
\text { with } \\
\text { AdS }(\mu \mathrm{M})\end{array}$ & $\begin{array}{l}\text { Bud- } \\
\text { break } \\
(\%)\end{array}$ & Response & $\begin{array}{l}\text { Length of the } \\
\text { plantlets }(\mathrm{cm}) \\
(\text { mean } \pm S E)\end{array}$ & $\begin{array}{l}\text { No.of roots } \\
(\text { mean } \pm S E)\end{array}$ \\
\hline 1 & 71.50 & $\begin{array}{l}\text { bud failed to } \\
\text { differentiate } \\
\text { but rooting } \\
\text { was observed }\end{array}$ & - & $8.70^{\mathrm{ab}} \pm 0.26$ \\
\hline 4 & 78.53 & $\begin{array}{c}\text { bud } \\
\text { differentiated } \\
\text { to plantlets }\end{array}$ & $2.12^{\mathrm{a}} \pm 0.16$ & $7.70^{\mathrm{b}} \pm 0.34$ \\
\hline 7 & 83.13 & $\begin{array}{c}\text { bud } \\
\text { differentiated } \\
\text { to plantlets }\end{array}$ & $2.62^{\mathrm{ab}} \pm 0.14$ & $6.70^{b} \pm 0.37$ \\
\hline 10 & 85.73 & $\begin{array}{c}\text { bud } \\
\text { differentiated } \\
\text { to plantlets }\end{array}$ & $3.94^{\mathrm{c}} \pm 0.11$ & $4.40^{\mathrm{a}} \pm 0.37$ \\
\hline 13 & 82.53 & $\begin{array}{c}\text { bud } \\
\text { differentiated } \\
\text { to plantlets }\end{array}$ & $3.24^{\mathrm{b}} \pm 0.06$ & $3.40^{\mathrm{a}} \pm 0.48$ \\
\hline
\end{tabular}

Means followed by same letters are not significantly different at $\mathrm{p}<0.05$, according to Tukey's comparison test
The possible growth regulatory effect caused by adenine was first noted by Bonner and Huagen-Smith (1939). It could induce bud formation in both tobacco stem segments and elm and tobacco callus in vitro (Bonner et al., 1939; Skoog and Tsui, 1948; Jacquiot, 1951; Miller and Skoog, 1953). In Nicotina tabacum, medium containing $\mathrm{Kn}$ and AdS showed marked increase in the activities of two enzymes of the oxidative pentose phosphate pathway, compared to their activities in non-shoot forming medium (Scott et al., 1964). Hence, it may be inferred that presence of BAP, NAA and AdS in the medium increases enzymes of the oxidative pentose phosphate pathway which provide activation energy for breaking bud dormancy through sucrose metabolism. After 4 weeks, propagules from $5 \mu \mathrm{M}$ BAP, $1 \mu \mathrm{M}$ NAA and 30-70 $\mathrm{gl}^{-1}$ sucrose and from $1 \mu \mathrm{M}$ NAA, $5 \mu \mathrm{M}$ BAP, 1-13 $\mu \mathrm{M}$ AdS and $50 \mathrm{gl}^{-1}$ sucrose supplemented MS medium were cultured on MS medium supplemented with $10 \mu \mathrm{M}$ AdS, $1 \mu \mathrm{M}$ NAA, 50 $\mathrm{gl}^{-1}$ sucrose and 3-11 $\mu \mathrm{M}$ BAP for shoots multiplication. The average number of multiple shoot increased as the concentration of BAP increased from 3-7 $\mu \mathrm{M}$. However, further increase was inhibitory (Tab. 3 and 4, Fig. $2 \mathrm{c}$ and d). Maximum average number of shoots, in both cases, was achieved in $7 \mu \mathrm{M}$ BAP (Tab. 3 and 4). BAP has almost the same effect on shoot multiplication of the propagules

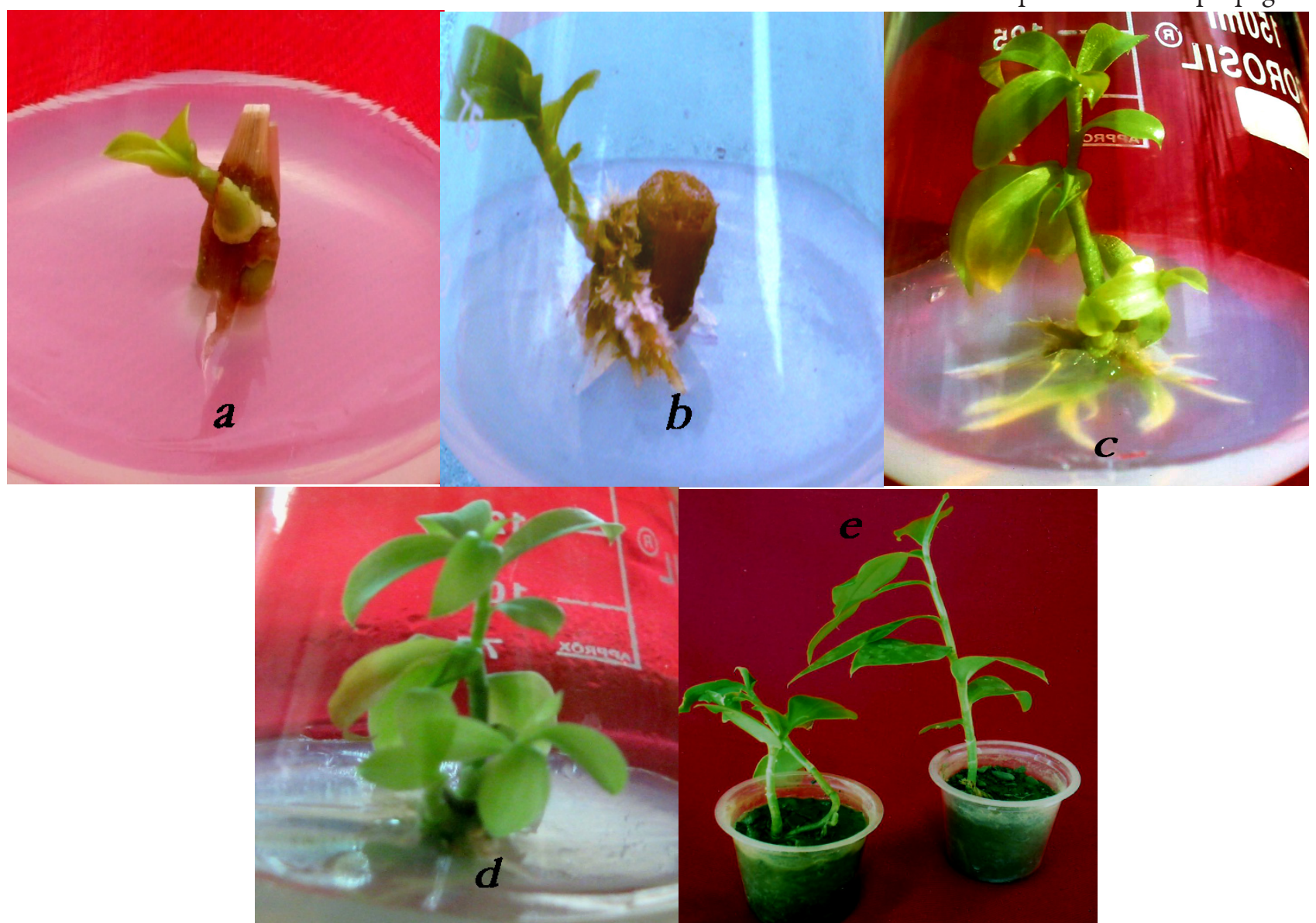

Fig. 2. Micropropagation of Costus speciosus; (a) Axillary bud-break in MS $+50 \mathrm{gl}^{-1}$ sucrose; (b) Axillary bud-break with roots in MS + 10 $\mu \mathrm{M}$ Ads; (c) Proliferation of propagules from 1-13 $\mu \mathrm{M}$ Ads in MS + 3 $\mu \mathrm{M}$ BAP; (d) Proliferation of propagules from 1-13 $\mu \mathrm{M}$ Ads in MS $+7 \mu \mathrm{M}$ BAP; (e) Transplanted plantlets established on soil 
Tab. 3. Effect of different concentration of BAP on shoot multiplication and rooting of propagules of Costus speciosus from 40-60 $\mathrm{gl}^{-1}$ sucrose enriched medium in MS medium

\begin{tabular}{cccc}
\hline $\begin{array}{c}\text { Treatment } \\
\text { with BAP } \\
(\mu \mathrm{M})\end{array}$ & $\begin{array}{c}\text { No. of shoots } \\
(\text { mean } \pm \text { SE) }\end{array}$ & $\begin{array}{c}\text { No. of roots } \\
(\text { mean } \pm \text { SE })\end{array}$ & $\begin{array}{c}\text { No. of leaves } \\
(\text { mean } \pm \text { SE) }\end{array}$ \\
\hline 3 & $1.20^{\mathrm{a}} \pm 0.25$ & $3.60^{\mathrm{b}} \pm 0.27$ & $2.17^{\mathrm{a}} \pm 0.23$ \\
5 & $1.80^{\mathrm{a}} \pm 0.26$ & $3.10^{\mathrm{b}} \pm 0.23$ & $2.96^{\mathrm{a}} \pm 0.20$ \\
7 & $3.30^{\mathrm{b}} \pm 0.25$ & $2.20^{\mathrm{a}} \pm 0.25$ & $3.23^{\mathrm{a}} \pm 0.24$ \\
9 & $2.20^{\mathrm{b}} \pm 0.30$ & $1.90^{\mathrm{a}} \pm 0.23$ & $3.25^{\mathrm{a}} \pm 0.22$ \\
11 & $1.60^{\mathrm{a}} \pm 0.34$ & $1.50^{\mathrm{a}} \pm 0.34$ & $3.16^{\mathrm{a}} \pm 0.24$ \\
\hline
\end{tabular}

Mean followed by the same letters are not significantly different

at $\mathrm{p}<0.05$, according to Tukey's comparison test

derived from 40-60 $\mathrm{gl}^{-1}$ sucrose and 1-13 $\mu \mathrm{M}$ AdS supplemented medium. Although, there was no significant difference between the average shoot numbers of two types of propagules, the plantlets produced from propagules of AdS supplemented medium were healthier and average number of leaves was also higher (Tab. 3 and 4). This is in agreement with the findings on Brassica campestris in which adding adenine sulphate to medium containing $\mathrm{Kn}$ and IBA did not increase shoot multiplication, but shoot weight increased, leaves were dark green and the cultures were healthy (Paek et al., 1987).

During bud-break and shoot multiplication experiment, rooting was observed only on medium supplemented with AdS in conjunction with BAP and NAA. The propagules from $40-60 \mathrm{gl}^{-1}$ sucrose supplemented medium were successfully rooted when transferred on to medium supplemented with $10 \mu \mathrm{M}$ AdS, $1 \mu \mathrm{M}$ NAA and 3-11 $\mu \mathrm{M}$ BAP. The maximum average number of roots was found in $3 \mu \mathrm{M}$ BAP treatment (Tab. 3). In the case of propagules from 1-13 $\mu \mathrm{M}$ AdS supplemented medium, further increase in average number of roots was observed, when transferred on to a medium supplemented with $10 \mu \mathrm{M}$ AdS, $1 \mu \mathrm{M}$ NAA, 3-11 $\mu \mathrm{M}$ BAP (Tab. 4). Start and Cumming (1976) have reported positive effect of AdS on rooting in Saintpaulia ionantha in the same trend as shown in the current results. The plant survival touches about $95 \%$

Tab. 4. Effect of different concentration of BAP on shoot multiplication and rooting of propagules of Costus speciosus from 1-13 $\mu \mathrm{M}$ AdS enriched medium in MS medium supplemented with $50 \mathrm{gl}^{-1}$ sucrose

\begin{tabular}{ccccc}
\hline $\begin{array}{c}\text { Treatment } \\
\text { with } \\
\text { BAP } \\
(\mu \mathrm{M})\end{array}$ & $\begin{array}{c}\text { No. of } \\
\text { shoots } \\
(\text { Mean } \pm \text { SE) }\end{array}$ & $\begin{array}{c}\text { No. of roots } \\
\text { (Mean } \pm \text { SE) }\end{array}$ & $\begin{array}{c}\text { Rooting rate } \\
\text { (Mean } \pm S E)\end{array}$ & $\begin{array}{c}\text { No. of leaves } \\
(\text { Mean } \pm \text { SE) }\end{array}$ \\
3 & $0.90^{\mathrm{a}} \pm 0.28$ & $12.80^{\mathrm{ab}} \pm 0.33$ & $3.20^{\mathrm{ab}} \pm 0.09$ & $9.80^{\mathrm{b}} \pm 0.33$ \\
5 & $2.00^{\mathrm{b}} \pm 0.21$ & $11.50^{\mathrm{ab}} \pm 0.50$ & $2.87^{\mathrm{ab}} \pm 0.13$ & $8.76^{\mathrm{a}} \pm 0.38$ \\
7 & $3.60^{\mathrm{ab}} \pm 0.27$ & $9.82^{\mathrm{b}} \pm 0.48$ & $2.45^{\mathrm{b}} \pm 0.12$ & $8.58^{\mathrm{a}} \pm 0.34$ \\
9 & $2.70^{\mathrm{b}} \pm 0.34$ & $8.88^{\mathrm{b}} \pm 0.54$ & $2.22^{\mathrm{b}} \pm 0.14$ & $8.06^{\mathrm{a}} \pm 0.35$ \\
\hline 11 & $1.40^{\mathrm{a}} \pm 0.31$ & $7.30^{\mathrm{a}} \pm 0.37$ & $1.82^{\mathrm{a}} \pm 0.10$ & $7.39^{\mathrm{a}} \pm 0.36$ \\
\hline
\end{tabular}

Mean followed by the same letters are not significantly different at $\mathrm{p}<0.05$, according to Tukey's comparison test when acclimatization is carried out by transferring the plantlets to potting mixture (Fig. $2 \mathrm{e}$ ).

\section{Conclusions}

Nodal segment culture provides new technique for micropropagation of Costus speciosus. It also overcomes many disadvantages of rhizomatous eye/bud or shoots tip culture, while one mature stem usually contain 15-20 axillary buds in comparison to $4-5$ rhizomatous eye in one rhizome. Further induction of multiple shoot from plantlets resulted in regeneration of a large number of plantlets from a single stem. The plant survival touches about $95 \%$ when acclimatization is carried out by transferring the plantlets to potting mixture.

\section{References}

Bonner, D. M. and A. J. Haagen-Smith (1939). Leaf growth factors II. The activity of pure substances in leaf growth. Proc. Nat. Acad. Sci. U.S.A. 25:184-188.

Bonner, D. M., A. J. Haagen-Smith and F. W. Went (1939). Leaf growth hormones. 1. A bio-assay and source for leaf growth factors. Bot. Gaz. 101:128-144.

Chaturvedi, H. C., P. Misra and M. Jain (1984). Proliferation of shoot tips and clonal multiplication of Costus speciosus in long term culture. Plant Sci. Letts. 35:67-71.

Chopra, R. N., S. L. Nayer and I. C. Chopra (1956). Glossary of Indian medicinal plants. New Delhi: CSIR Publication and Information Directorate. 78-79.

Dasgupta, B. and V. B. Pandey (1970). A new Indian source of diosgenin (Costus speciosus). Cell. Molec. Life Sci. 26:475476.

Deb, D. B. (1983). The Flora of Tripura State. BuddlejaceaeGramineae (Poaceae). Today and Tomorrow's Printers and Publishers. Vol. II.

Eliza, J., P. Daisy, S. Ignacimuthu and V. Duraipandiyan (2009a). Normo-glycemic and hypolipidemic effect of costunolide isolated from Costus speciosus (Koen.) Sm. in streptozotocin induced diabetic rats. Chem. Biol. Interact.179:329-334.

Eliza, J., P. Daisy, S. Ignacimuthu and V. Duraipandiyan (2009b). Antidiabetic and antilipidemic effect of eremanthin from Costus speciosus (Koen.) Sm. in STZ induced diabetic rats. Chem. Biol. Interact. 182:62-72.

Jacquiot, C. (1951). Action of meso-inositol and of adenine on bud formation in the cambium tissue of Ulmus campestris cultivated. In vitro Compt. Rend. Acad. Sci. Paris. 233:815817.

Khanna, P., G. L. Sharma, A. K. Rathore and S. K. Manot (1977). Effect of cholesterol on in vitro suspension tissue cultures of Costus speciosus (Keon.) Sm. Dioscorea floribunda, Solanum aviculare and Solanum xanthocarpum. Ind. J. Exptl. Biol. 15:1025-1027.

Langridge, W. H. R., K. J. Fitzgerald, C. Koncz, J. Schell and 
62

A. A. Szalay (1989). Dual promoter of Agrobacterium tumefaciens mannopine synthase genes is regulated by plant growth hormones. Proc. Natl. Acad. Sci. USA 86:32193223.

Malabadi, R. B., G. S. Mulgand and K. Nataraja (2005). Effect of Triacotanol on the micropropagation of Costus speciosus (Koen.) Sm. using rhizome thin sections. In vitro Cell Dev. Biol.-Plant. 41:129-132.

Miller, C. and F. Skoog (1953). Chemical control of bud formation in tobacco stem segments. Am. J. Bot. 40:768773.

Murashige, T., F. Skoog (1962). A revised medium for rapid growth and bioassays with tobacco tissue cultures. Physiol. Planta. 15:473-497.

Paek, K. Y., S. F. Chandler and T. A. Thorpe (1987). In vitro propagation of Chinese cabbage from seedling shoot tips. J. Am. Soc. Hort. Sci. 112:841-845.

Pearce, D. W., J. S. Taylor, J. M. Robertson, K. N. Harker and E. J. Daly (1995). Changes in abscisic acid and indole-3-acetic acid in axillary buds of Elytrigia repens released from apical dominance. Physiol. Planta. 94:110-116.

Pilate, G., B. Sotta, R. Maldiney, L. M. Jacques, Sossountzov and E. Miginiac (1989). Absccisic acid, IAA and cytokinin changes in buds of Pseudotsuga menziesii during bud quiescence release. Physiol. Planta. 76:100-106.

Prakash, V. and B. N Mehrotra (1996). Zingiberaceae of India: Biological screening and ethnobotanical diversity: In Proceedings of the second Symposium on the family Zingiberaceae, South China Institute of Botany. 229-237.

Rastogi, R. P. and B. N. Mehrotra (1991). Compendium of Indian medicinal plants. p.81-84, vol.2 (1970-1979). Lucknow, India: Central Drug Research Institute (CDRI).

Rathore, A. K. and P. Khanna (1978). Production of diosgenin from Costus speciosus (Koen.) Sm. and Solanum nigram L. suspension cultures. Curr. Sci. 47:870-871.

Scott, K. J., J. Daly and H. H. Smith (1964). Effects of indoleacetic acid and kinetin on activities of enzymes of the hexose monophosphate shunt in tissue cultures of Nicotiana. Plant Physiol. 39:709-712.

Skoog, F. and C. Tsui (1948). Chemical control of growth and bud formation in tobacco and callus cultured. In vitro. Am. J. Bot. 35:782-787.

Start, N. G. and B. G. Cumming (1976). In vitro propagation of Saintpaulia ionantha Wendl. HortScience 11:204-206. 